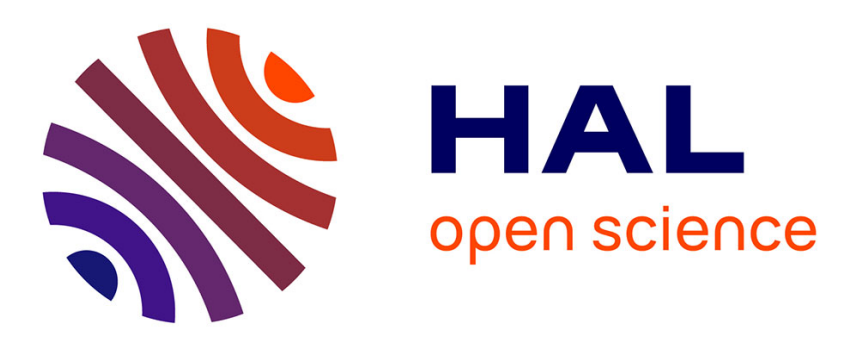

\title{
Upregulation of enteric alpha-synuclein as a possible link between inflammatory bowel disease and Parkinson's disease
}

\author{
Pascal Derkinderen, Wendy Noble, Michel Neunlist, Malvyne \\ Rolli-Derkinderen
}

\section{To cite this version:}

Pascal Derkinderen, Wendy Noble, Michel Neunlist, Malvyne Rolli-Derkinderen. Upregulation of enteric alpha-synuclein as a possible link between inflammatory bowel disease and Parkinson's disease. Gut, In press, 10.1136/gutjnl-2020-323482 . hal-03153624

\section{HAL Id: hal-03153624 \\ https://cnrs.hal.science/hal-03153624}

Submitted on 8 Mar 2021

HAL is a multi-disciplinary open access archive for the deposit and dissemination of scientific research documents, whether they are published or not. The documents may come from teaching and research institutions in France or abroad, or from public or private research centers.
L'archive ouverte pluridisciplinaire HAL, est destinée au dépôt et à la diffusion de documents scientifiques de niveau recherche, publiés ou non, émanant des établissements d'enseignement et de recherche français ou étrangers, des laboratoires publics ou privés. 
Upregulation of enteric alpha- synuclein as a possible link between inflammatory bowel disease and Parkinson's disease

\section{Pascal Derkinderen ,1 Wendy Noble,2 Michel Neunlist,1 Malvyne Rolli-Derkinderen ${ }^{1}$}

1Université de Nantes, Inserm, TENS, The Enteric Nervous System in Gut and Brain Diseases, IMAD, Nantes, France

2Department of Basic and Clinical Neuroscience, King's College London, Institute of Psychiatry, Psychology and Neuroscience, London, UK

Correspondence to Dr Pascal Derkinderen, University of Nantes, Nantes, France;

derkinderenp@yahoo.fr

Contributors All authors contributed to the text. PD prepared the figure.

Funding The authors have not declared a specific grant for this research from any funding agency in the public, commercial or not-for-profit sectors.

Competing interests None declared.

Patient and public involvement Patients and/or the public were not involved in the design, or conduct, or reporting, or dissemination plans of this research.

Patient consent for publication Not required.

Received 26 October 2020

Revised 29 October 2020 Accepted 3 November 2020

Gut 2020;0:1-2. doi:10.1136/gutjnl-2020-323482

Ethics approval The study protocol on colonic biopsies was approved by the local Committee on Ethics and Human Research (Comité de Protection des Personnes Ouest VI). Written informed consent was obtained from each patient and from each control volunteer before the endoscopic procedure. All procedures were performed according to the guidelines of the French Ethics Committee for Research on Humans and registered under the no. DC-2008402. 
With interest, we read the review by Lee et al on the possible link between inflammatory 1 bowel disease and Parkin- son's disease. After reviewing the recent evidence showing that inflammatory bowel disease and Parkinson's disease are epidemiologically and genetically linked, the authors discuss the potential shared biological mechanisms between these two seemingly unrelated disorders. In this context, they briefly discuss the possible role of alphasynuclein, a neuronal protein which is not only expressed in both the gut and brain but that is also a key compo- nent of Parkinson's disease pathology. 2 They summarise their literature analysis by saying that 'Expression of $\alpha$-synuclein in both the gut and brain of Parkinson's disease patients represents a possible link between Parkinson's disease and inflam- matory bowel disease. However, the precise mechanism and role of enteric alpha-synuclein remain unknown'.1

A
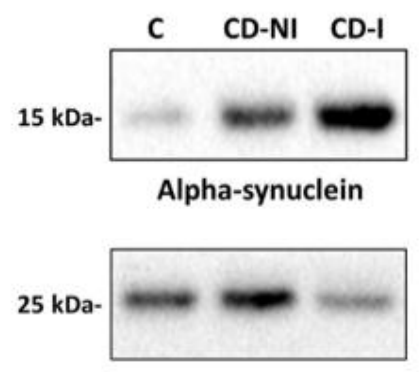

PGP 9.5

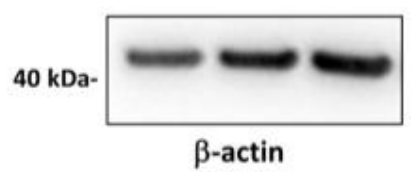

B Full-thickness segments of colon
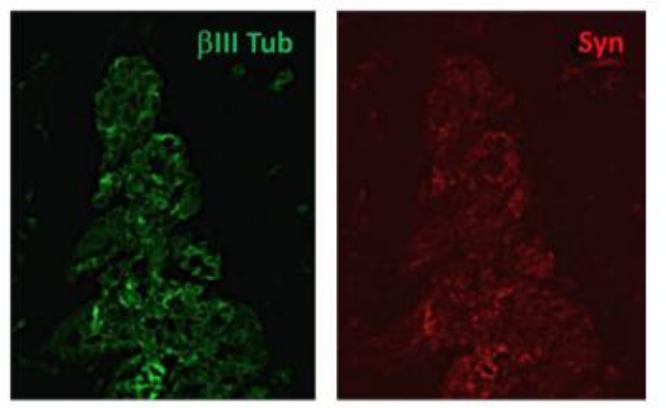

Control
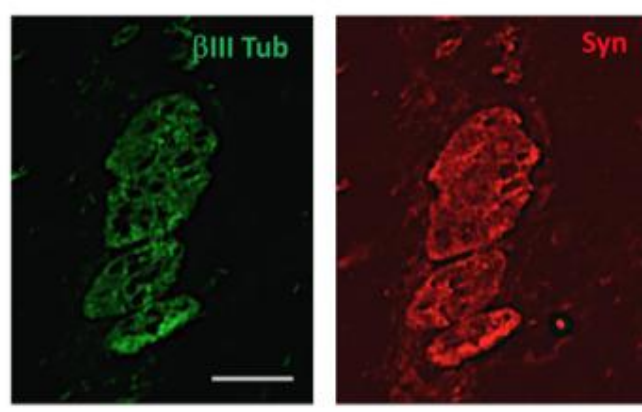

CD-I

Figure 1 Expression levels of alpha-synuclein protein in colon from patients with Crohn's disease (CD) and controls. (A) Colonic biopsy lysates from one CD patient (patient \#381, see reference 3) and one control (C) were subjected to immunoblot analysis using antibodies against alphasynuclein MJFR1 (1:1,000; Abcam, Paris, France) or mouse monoclonal anti-PGP 9.5 (1:2000; Ultraclone limited, Isle of Wight, UK). To confirm equal protein loading, membranes were probed with mouse monoclonal anti- $\beta$-actin antibody $(1: 10,000$; sigma, Saint-Quentin-Fallavier, France). For the CD subject, biopsies taken in non-inflammatory (CD-NI) and inflammatory area (CD-I) were analysed separately. A markedly increased expression of alpha-synuclein is observed in the non-inflamed and inflamed area of the CD patient when compared with control. (B) Antialpha-synuclein Syn-1 (syn, 1:500; BD bioscience, Le Pont-De-Claix, France) and rabbit polyclonal anti- $\beta$-tubulin III antibody ( $\beta$ III tub, 1:1000; Abcam) were used to detect alphasynuclein in the myenteric ganglia in CD and control subjects. Alpha-synuclein immunoreactivity is increased in myenteric neurons of the CD patient when compared with the control subject. Scale bar is $50 \mu \mathrm{m}$.

Although we agree with the authors that the mechanisms by which gastrointestinal inflammation might influence Parkinson's disease development or progression are still unclear, we would like to draw their attention to two recently published arti- cles by our group in which we showed that alpha-synuclein accumulates in the colon of Crohn's disease patients.3 4 Using biop- sies and full-thickness segments of colon from Crohn's disease subjects ( $n=10$ and 4, respectively) and controls ( $n=12$ and 4, respectively), we observed an 
increased expression of alpha-synuclein in both the submucosal and myenteric plexus in Crohn's disease relative to controls3 (figure 1). Additional experiments

performed in primary cultures of enteric neurons and using nuclear factor eryth- roid 2related factor 2 (Nrf2) knockout mice allowed us to show that this upreg- ulation was not transcriptionally regu- lated but instead likely resulted from a decrease in protein clearance via an Nrf2 pathway. 4 In the context of Parkinson's disease, this observation suggests that a sustained gastrointestinal inflammation might increase alpha-synuclein expression in the submucosal neurons whose terminal axons are only micrometres away from the gut lumen, thereby enabling pathological protein accumulation and propagation of abnormal proteins to the brain via the vagal innervation. 5

If such a hypothesis is true, one critical pending issue is to determine why only a subset of patients with inflammatory bowel disease will eventually develop Parkin- son's disease. In a recent opinion paper, it has been proposed that Parkinson's disease pathogenesis can be divided into three different temporal phases6: 'trig- gers', which set off the disease process in the brain and/or peripheral tissues, 'facilitators' that help triggers access the nervous system or spread the pathology within the brain and 'aggravators', which may increase alpha-synuclein spreading. Based on this conceptual model, one might, therefore, suggest that inflamma- tory bowel disease-induced gastrointes- tinal inflammation may act as a facilitator of Parkinson's disease pathology.

\section{REFERENCES}

1. Lee H-S, Lobbestael E, Vermeire S, et al. Inflammatory bowel disease and Parkinson's disease: common pathophysiological links. Gut 2020;380:gutjnl-2020-322429.

2. De Guilhem De Lataillade A, Lebouvier T, Noble W, et al. Enteric synucleinopathy: real entity or only a trendy concept? Free Neuropathology 2020;26:Seiten.

3. Prigent A, Lionnet A, Durieu $E$, et al. Enteric alpha- synuclein expression is increased in Crohn's disease. Acta Neuropathol 2019;137:359-61.

4. Prigent A, Chapelet G, De Guilhem de Lataillade A, et al. Tau accumulates in Crohn's disease gut. Faseb J 2020;34:9285-96.

5. Borghammer P, Van Den Berge N. Brain-First versus Gut-First Parkinson's disease: a hypothesis. J Parkinsons Dis 2019;9:S281-95.

6. Johnson ME, Stecher B, Labrie V, et al. Triggers, facilitators, and Aggravators: redefining Parkinson's disease pathogenesis. Trends Neurosci 2019;42:4-13. 